\title{
ADMINISTRAÇÃO PÚBLICA E O PRINCÍPIO CONSTITUCIONAL DA EFICIÊNCIA
}

\author{
EDILSON PEREIRA NOBRE JÚNIOR*
}

\begin{abstract}
1. Administração pública e pós-modernismo (à guisa de introdução); 2. breve visão do direito estrangeiro; 3. o significado e a natureza da eficiência administrativa; 4. a positivação do princípio da eficiência no direito brasileiro antes e depois da Emenda Constitucional 19/98; 5. o princípio e sua influência nos institutos administrativos; 6 . limites e controle jurisdicional da eficiência; 7. conclusões.
\end{abstract}

\section{Administração pública e pós-modernismo (à guisa de introdução)}

Convencionou-se, na seara doutrinária, denominar pós-positivismo o movimento que, pregando o abandono ao positivismo estrito, enxerga as manifestações do direito além da figura outrora idolatrada da lei. E não é só. Insiste, a partir da forte carga valorativa consagrada pelo constitucionalismo do segundo pós-guerra, na primazia dos princípios como pilastras fundantes do sistema jurídico ${ }^{1}$.

* Juiz Federal. Professor da Universidade Federal do Rio Grande do Norte e do Programa de Pós-graduação em Direito da Faculdade de Direito do Recife - UFPE (mestrado e doutorado). Mestre e Doutor em Direito Público pela Faculdade de Direito do Recife - UFPE.

1 Mateus Eduardo Siqueira Nunes Bertoncini (Princípios de direito administrativo brasileiro. São Paulo: Malheiros, 2002. p. 36-50) alude a pós-positivismo para explicar a tendência, prevalecente na atualidade, de reputar os princípios como normas superiores do sistema jurídico. Também compulsar Luís Roberto Barroso (Fundamentos teóricos e filosóficos do novo direito constitucional brasileiro: pós-modernidade, teoria crítica e pós-positivismo. Revista de Direito Administrativo. Rio de Janeiro, n. 225, p. 24-33, jul./set. 2001) e George Salomão Leite \& Glauco Salomão Leite (A abertura da Constituição em face dos princípios constitucionais. In: LEITE, George Salomão (Coord.) Dos principios constitucionais - consideraçōes em torno das normas principiológicas da Constituição. São Paulo: Malheiros, 2003. p. 140-142.).

R. Dir. Adm.,

Rio de Janeiro, 241: 209-240,

Jul./Set. 2005 
Assim, as normas jurídicas passaram a ser, grosso modo, divididas em princípios e regras. Sem a preocupação de exaurir todos os critérios distintivos ${ }^{2}$, tem-se, na feliz observação de Willis Santiago Guerra Filho ${ }^{3}$, que estas se revelam por serem dotadas do binômio hipótese-consequiência, como, por exemplo, constata-se do art. 41, caput, da Constituição vigente, ao prever a aquisição da estabilidade, por parte do servidor titular de cargo efetivo, após o cumprimento do estágio probatório de três anos.

Os princípios, diferentemente, incorporam valores ${ }^{4}$ que, uma vez integrados no ordenamento, adquirem positividade. Nesse sentido, a proclamação, contida no art. $5^{\circ}$, I, da CF, de que todos são iguais perante a lei, mostra padrão que deve servir de bússola à aplicação do direito diante dos casos concretos.

Ao invés das regras, cuja aplicação é renovada cada vez em que repetida a situação fática nelas descrita, os princípios propiciam ao julgador uma maior liberdade de apreciação, de modo a aproximar a solução dos casos concretos aos mandamentos nucleares do sistema jurídico e ao ideal de justiça.

Não olvidar também critério, atualmente bastante em voga, delineado por Robert Alexy, para quem os princípios são mandatos de otimização. Em contrapartida às regras, que podem ser cumpridas ou não, tem-se que:

O ponto decisivo para a distinção entre regras e princípios é que os principios são normas que ordenam que algo seja realizado na maior medida possível, dentro das possibilidades jurídicas e reais existentes. Portanto, os princípios

2 Rodolfo L. Vigo (Los principios juridicos. Buenos Aires: Depalma, 2000. p. 9-18) arrola, em denso levantamento, vinte e quatro critérios que distinguem os princípios das regras, muito embora denomine estas de normas. Por sua vez, Luis Prieto Sanchís (Sobre principios y normas-problemas del razonamento juridico. Madri: Centro de Estudios Constitucionales, 1992. p. 56-64) enfatiza que, sendo espécie do gênero normas, os princípios se diferenciam pela fundamentalidade jurídico-política que assumem no trabalho hermenêutico, aliada à sua estrutura morfológica, caracterizada por uma maior generalidade e vaguidade. Para Larenz (Derecho justo - fundamentos de ética jurídica. Tradução: Luis Diéz-Picazo. Madri: Civitas, 1985. p. 36) não é o grau de generalidade o fator decisivo para a identificação dos princípios, o qual resulta de sua aptidão como causa de justificação e sua impressão numa regulação ou em várias.

3 Notas em torno ao princípio da proporcionalidade. In: MIRANDA, Jorge (Org.). Perspectivas constitucionais nos 20 anos da Constituição de 1976. Coimbra: Coimbra Editora, 1996. v. I, p. 249.

4 Digno de leitura o paralelo entre princípios e valores gizado na pena de Luís S. Cabral de Moncada (Os princípios gerais de direito e a lei. In: Estudos de Direito Público. Coimbra: Coimbra Editora, 2001. p. 413-414). Para o autor, estes consistem nos fundamentos ou critérios que constatam determinadas realidades morais (todos nascemos iguais e devemos amar o próximo como a nós mesmos, a revelar os valores da igualdade e do amor), enquanto aqueles se dirigem a orientar a nossa conduta nos planos individual e social (o legislador não deve discriminar entre os homens por motivos de raça ou religião, bem como adotar normas que proíbam tais práticas, expressando, desse modo, o princípio geral da não-discriminação). Observe-se também Edilsom Pereira de Farias (Colisão de direitos - a honra, a intimidade, a vida privada e a imagem versus a liberdade de expressão e informação. Porto Alegre: Sérgio Fabris Editor, 2000. p. 52-54), o qual resenha diversas posiçōes que, no âmbito doutrinário, procuram diferençar princípios de valores. 
são mandatos de otimização, que estão caracterizados pelo fato de que podem ser cumpridos em diferente grau e que a medida de seu cumprimento não só depende das possibilidades reais, mas também das jurídicas. O âmbito das possibilidades jurídicas é determinado pelos princípios e regras opostos ${ }^{5}$.

A essa tendência, notabilizada não pela aferição da existência dos princípios, mas, sobretudo, pelo inegável reconhecimento de seu componente normativo, não escapou o direito público e, especialmente, o direito administrativo.

Para tanto, o princípio da legalidade, tão caro aos administrativistas, sofreu sensível mutação de perfil. Não mais representa, como compreendeu a doutrina tradicional ${ }^{6}$, a subordinação da administração à lei formal, elaborada pelo Parlamento, situada no cume das fontes jurígenas. Expressa, ao invés, a idéia de conformação com o Direito.

Assim se tem vislumbrado dos recentes textos constitucionais, não sendo demasiado recordar que a Lei Fundamental alemã, no seu art. 20.3, proclama que o legislador está sujeito à ordem constitucional, enquanto que o Executivo e o Judiciário, à lei e ao Direito, o que vem repetido pela Constituição espanhola (art. 103.1, parte final) 7 . A seu turno, a Constituição Política da República do Chile (art. 6), de 1980, com a reforma de 1997, afirma que o Estado deve observar em sua ação a Constituição e as normas ditadas em conformidade com aquela.

Nesse diapasão, vem sendo objeto de reconhecimento indiscutível pela doutrina a presença de princípios que informam peculiarmente o regime jurídico da função administrativa. Jean Rivero ${ }^{8}$, invocando precedentes do Conselho de Estado (26 de

5 "El punto decisivo para la distinción entre reglas y principios es que los principios son normas que ordenan que algo seja realizado en la mayor medida posible, dentro de las posibilidades jurídicas y reales existentes. Por lo tanto, los principios son mandatos de optimización, que están caracterizados por el hecho de que pueden ser cumplidos en diferente grado y que la medida debida de su cumplimento no sólo depende de las posibilidades reales sino también de las jurídicas. El ámbito de las posibilidades jurídicas es determinado por los principios y reglas opuestos". (Teoría de los Derechos Fundamentales. Tradução para o espanhol: Ernesto Garzón Valdés. 3*. reimpressão. Madri: Centro de Estudios Politicos y Constitucionales, 2002. p. 86).

6 Observando-se Otto Mayer (Derecho Administrativo Alemán - Parte general. Tradução do original em francês: Horacio H. Heredia e Ernesto Krotoschin. 2. ed. Buenos Aires: Depalma, 1982. Tomo I, p. 161-180) precursor do direito administrativo alemão, ao se ocupar das fontes do direito administrativo, vê-se a indicação da lei, emitida segundo as prescrições constitucionais, como provedora do posto mais elevado da ordem administrativa, estando omitida, a esse respeito, qualquer referência aos princípios.

7 De conferir ainda que o art. 9.1 da Constituição hispânica menciona que os cidadãos e os poderes públicos estão sujeitos à Constituição e ao resto do ordenamento jurídico.

8 Direito administrativo. Tradução: Rogério Ehrhardt Soares. Coimbra: Almedina, 1981. p. 86-87. Quanto à recepção dos princípios gerais do direito administrativo, Juan Carlos Cassagne (Los principios generales del derecho en el derecho administrativo. Buenos Aires: Abeledo-Perot, 1992. p. 84-93) afirma que, além daqueles expressamente positivados nas constituiçð̃es, há que se incluir os que surgem implicitamente e informam o ordenamento constitucional, os que, à míngua de disciplina positiva, emergem do direito natural, os que provêm do Código Civil, cuja remota origem transcende do direito romano (enriquecimento sem causa e boa-fé), e aqueles que, também 
outubro de 1945 e 14 de abril de 1961) e do Conselho Constitucional (26 de junho de 1969), indica a existência de princípios gerais do direito administrativo, cuja origem remonta à tradição liberal de 1789 (igualdade dos cidadãos, liberdade de consciência, direito de defesa), a imperativos de eqüidade (vedação ao enriquecimento sem causa) e a necessidades da vida social (continuidade dos serviços públicos e hierarquia).

Particular atenção desperta essa última classe de princípios, já que não decorrem de ideais de justiça consagrados imemorialmente, mas de reclamos impostos pela vida gregária. Entre eles, pode-se, com facilidade, apontar o postulado da eficiência, que permeia o modo de gestão do Estado atual, com vistas a uma melhor satisfação do bem-estar geral.

A delimitação do lastro substancial desse princípio constitui o desafio deste escrito. Para tanto, será indispensável a análise de sua consagração por outros sistemas jurídicos e os antecedentes por nós experimentados até a promulgação da Emenda Constitucional 19/98.

\section{Breve visão do direito estrangeiro}

A exigência de que a atividade administrativa seja influenciada pela eficiência não é estranha a outros ordenamentos. Exemplo interessante se centra, de início, na Constituição italiana de 1947, cujo art. 97.1 proclama: "Os órgãos públicos são organizados segundo disposições de lei, de modo que sejam assegurados o bom andamento e a imparcialidade da administração" 9 .

Voltando-se à delimitação de ditos princípios, de perfil semântico indeterminado, Sandulli ${ }^{10}$ afirma que aos mesmos foi assinado um duplo significado. Num plano

constantes do Código Civil, possuem seu primeiro fundamento de natureza constitucional, inerente ao Estado de Direito (responsabilidade estatal direta e objetiva, sem vínculo com a idéia de culpa, a responsabilidade pela atividade legítima do Estado e pelas atuações legislativa e judicial), os de aceitação geral na esfera penal substantiva (nullum crimen, nulla poena sine lege e non bis in idem), os emanados do direito internacional público (os consagrados em tratados que passam a integrar o ordenamento estatal, como o Pacto de São José da Costa Rica, que derrogou a regra do solve et repete) e os provenientes das peculiaridades das instituições administrativas (continuidade do serviço público, estado de necessidade para respaldar regulamentos de urgência, a interpretação favorável ao particular nos contratos de atribuição, com a inversão da sistemática quanto aos contratos de colaboração, a autotutela coativa na proteção do domínio público, a criação de obrigações por ato administrativo unilateral, a irrevogabilidade dos atos administrativos criadores de direitos subjetivos, a necessidade de motivação dos atos administrativos que afetem direitos individuais ou coletivos, o silêncio administrativo em favor do particular, a presunção de legitimidade e a executoriedade dos atos administrativos).

9 "I pubblici uffici sono organizzati secondo disposizioni di legge, in modo che siano assicurati il buon andamento e l'imparzialitá dell'amministrazione" (Disponível em: www.constitution.org. Acesso em: 31 jan. 2002. Tradução livre).

10 Il procedimento. In: CASSESE. Sabino (Coord.). Trattato di diritto amministrativo - Diritto amministrativo generale. Milão: Dott. A. Giuffrè Editore, 2000. Tomo secondo, p. 956-7. 
restrito, mais aproximado à literalidade das expressões, atribuiu-se à imparcialidade a proibição de proceder a preferências, enquanto que ao bom andamento foi reservada uma exigência de boa administração. Partindo-se a uma visão mais ampla, legou-se à imparcialidade o poder-dever da Administração de avaliar e ponderar os interesses emergentes no procedimento e de adotar as consequientes escolhas. Já o bom andamento foi visto como necessidade de eficácia e de eficiência da ação, de sorte a consentir a persecução de resultados adequados.

Muito embora já se possa identificar o nosso objeto de estudo mais com o bom andamento do que com a imparcialidade, adianta o autor que a compreensão levada a cabo pela ciência jurídica considerou ambos os princípios como duas faces de uma mesma medalha, ou seja, como uma hendíade ${ }^{1}$ que articula um conceito unitário de legalidade.

Enfático, Franco Bassi considera sinônimos os princípios da boa administração e da eficiência, afirmando: "Segundo tal princípio a P.A. deve usar, na própria ação, a média diligência e a média inteligência e deve respeitar as $c . d$. regras de boa administração, de modo a assegurar a eficiência da atividade administrativa" 12 .

No desenvolvimento de sua exposição, às páginas $64 \mathrm{a} 65$ da obra citada, sumaria a seguinte idéia: a) a boa administração ou eficiência faz com que o modo de atuar da autoridade administrativa não seja irrelevante para o legislador, o qual não requer a solução ótima, mas a média, isto é, aquela da qual seja capaz o administrador médio, figura equiparada à do bonus pater familias, a que faz menção o direito privado, mais especificamente o art. 1.176 do Código Civil de $1942^{13}$; b) o princípio acarreta o reclamo de individualização das regras de boa administração, a serem deduzidas da moral ou das regras de experiência, as quais assumirão importância por causa do relevo que lhe atribui o ordenamento; c) a concreção do postulado delineia o fenômeno da praxe administrativa, através do qual se tem o desenvolvimento da ação administrativa sob modelo preestabelecido e que é fruto da experiência do agente, bem como do órgão objetivamente considerado, de maneira que, caso

11 No original, é utilizado o vocábulo endiadi, o qual espelha figura retórica capaz de exprimir um conceito através de dois termos coordenados. Em vernáculo, pode ser traduzido por hendíadis ou hendíade (Antônio Houaiss. Dicionário eletrônico Houaiss da Língua Portuguesa, versão 1.0, 2001).

12 "Secondo tale principio la P.A. deve usare, nella própria azione, la media diligenza e la media intelligenza e deve rispettare le c.d. regole di buona amministrazione in modo da assicurare l'efficienza dell' attività amministrativa" (Lezioni di diritto amministrativo. Milão: Dott. A. Giuffrè Editore, 1995. p. 63. Tradução livre)

13 Para uma melhor compreensão, transcrevemos referido dispositivo: “Quando do cumprimento da obrigação o devedor deve usar a diligência do bom pai de família. No cumprimento das obrigações inerentes ao exercício de uma atividade profissional a diligência deve ser avaliada relativamente à natureza da atividade exercitada" (Nell'adempire lóbbligazione il debitore deve usar ela ciligenza dei buon padre di família. Nell'adempimento delle obbligazioni inerenti di um'attività professionale la diligenza deve valutarsi con riguardo alla natura dell'attività esercitada" (Disponível em: www.studiocelentano.it. Acesso em: 12 mar. 2002. Tradução livre). 
advenha bom resultado, constituirá precedente com o qual os funcionários, em hipóteses análogas, inspirar-se-ão para modificar seu agir.

Singular atenção aos princípios da eficiência e do bom andamento da Administração, com o propósito de salvaguardar o interesse público, legou a Legge 241, de 07 de agosto de 1990 , cujo art. $1^{\circ}$ destaca que a atividade administrativa persegue os fins determinados pela lei, devendo render atenção aos critérios de economicidade, de eficácia e de publicidade.

Tal característica, como aponta Guido Corso ${ }^{14}$, faz-se presente, de forma detalhada, no seu IV Capítulo, a englobar as disposições sobre a simplificação do procedimento, estabelecidas em favor do cidadão, beneficiário da celeridade do agir administrativo, e que, sob outro prisma, também buscam garantir a eficiência da Administração.

Daí seguem: a) as conferências de serviços, realizadas entre os representantes dos interesses públicos envolvidos no procedimento, das quais surgem resoluções que vinculam as Administrações implicadas, substituindo os atos que cada uma delas pretendia adotar (art. 14); b) os acordos entre entes públicos para o desenvolvimento de colaboração em atividades de interesse comum (art. 15); c) possibilidade de tomada de decisões com a dispensa de prévia manifestação consultiva obrigatória, desde que esta não seja proferida no respectivo prazo, salvo no que concerne a assuntos ambientais e paisagísticos (art. 16); d) permissão, nas hipóteses de procedimentos onde necessário informe de caráter técnico, para o órgão de administração ativa, na inércia do órgão consultivo competente, dirigir-se a outro órgão técnico ou instituto universitário (art. 17); e) a autocertificação de documentos (art. 18); f) novo regime de autorizações administrativas, através do qual estas são substituídas pelo comunicado do início da atividade pelo interessado, conferindo-se à Administração a competência para a sua proibição quando, posteriormente, seja comprovada a falta dos pressupostos legais (art. 19) ${ }^{15}$.

Também merece ser analisado o sistema jurídico português. A Constituição da República, no art. $267^{\circ}$, logo após referir-se no seu $n^{\circ} 1^{\circ}$ que a Administração deva ser estruturada de modo a evitar a burocratização, com vistas a aproximar os seus serviços da população e assegurar a participação dos interessados em sua gestão efetiva, alude, no $\mathrm{n}^{\circ} 2^{\circ}$, a que a lei estabelecerá formas de descentralização e desconcentração administrativas, sem prejuízo da necessária eficácia da ação dos órgãos competentes.

O termo constitucional eficácia, no dizer de Luís S. Cabral de Moncada ${ }^{16}$, configura autêntico princípio jurídico, do qual advém para a Administração um dever

14 El procedimiento administrativo en Italia. In: BARNES VAZQUEZ, Javier (Coord.). El procedimiento administrativo em el derecho comparado. Madri: Civitas, 1993. p. 494.

15 Mesmo não situado no referido Capítulo IV, de conferir-se ainda o encargo de conclusão do procedimento, por decisão expressa, no intervalo de trinta dias, salvo previsão diversa em lei ou regulamento.

16 Direito público e eficácia. In: Estudos de Direito Público. Coimbra: Coimbra Editora, 2001. p. 171. 
positivo de atuação, relacionado com os resultados da atividade por aquela desenvolvida. O postulado se volta ao modo de organização do aparato administrativo e de desempenho da atividade deste.

Do seu desdobramento surge, no plano legal, como assinalam Santos Botelho, Pires Esteves e Cândido de Pinho ${ }^{17}$, o princípio da eficiência, consagrado no art. $10^{\circ}$ do Código do Procedimento Administrativo ${ }^{18}$, promulgado pelo Decreto-lei 442, de 15 de novembro de 1991.

Não obstante um pouco de confusão terminológica ${ }^{19}$, a projeção da eficácia sobre a atividade administrativa, através da imposição legislativa de decisões eficientes, implica a opção pela celeridade, informalismo, simplicidade e economia processual, inconciliável com deliberações delongadas e dotadas de desmedida burocratização.

Por sua vez, ajunta Luís S. Cabral de Moncada $^{20}$ que da eficácia, no âmbito do procedimento administrativo, poderá ensejar a consagração da necessidade de concluir-se procedimento sancionatório em prazo razoável, pena de sua caducidade, e a possibilidade do término convencional do procedimento administrativo, como é a hipótese da estipulação de cláusula de resolução arbitral entre os particulares e a Administração, contribuindo-se para a propagação de um ambiente de confiança entre ambos.

Interessante, ao encerrar a referência ao direito português, a transcrição do que a doutrina portuguesa vem entendendo por eficiência, uma das vertentes do princípio magno da eficácia. Vale citar Freitas do Amaral, João Caupers, Martins Claro, João Raposo, Dias Garcia, Siza Vieira e Pereira da Silva:

O princípio da desburocratização e da eficiência implica que a Administração Pública deva organizar-se por forma a possibilitar uma utilização racional dos meios ao seu dispor, simplificando tanto as suas operações como o relacionamento com os cidadãos ${ }^{21}$.

17 Código do Procedimento Administrativo anotado - comentado - jurisprudência. 2. ed. Coimbra: Almedina, 1992. p. 80.

18 O art. $10^{\circ}$ do diploma legal mencionado está assim redigido: “ A Administração Pública deve ser estruturada de modo a aproximar os serviços das populações e de forma não burocratizada, a fím de assegurar a celeridade, a economia e a eficiência das suas decisões".

19 Para Luís S. Cabral de Moncada (Direito público e eficácia. In: Estudos de Direito Público. Coimbra: Coimbra Editora, 2001. p. 169) a eficácia, além de não confundir-se com a mera aptidão de produzir efeitos das normas e atos jurídicos, tampouco se confunde com a mera eficiência, consistente na economia de recursos. Já Santos Botelho, Pires Esteves e Cândido de Pinho (Código do Procedimento Administrativo anotado - comentado - jurisprudencia. 2. ed. Coimbra: Almedina, 1992. p. 80) utilizam os vocábulos como sinônimos. Em minha opinião, partindo do vocábulo empregado pelo Constituinte, o direito português denominou o que conhecemos pelo princípio da eficiência como eficácia, universo que, nas plagas lusitanas, abarca a eficiência, uma de suas concreções na esfera infraconstitucional.

20 Direito público e eficácia. In: Estudos de Direito Público. Coimbra: Coimbra Editora, 2001. p. 191-192. 
Oportuno ainda o comentário de Esteves de Oliveira, Costa Gonçalves e Pacheco de Amorim:

A celeridade, a economia e a eficiência das suas decisões são parâmetros em função dos quais a Administração deve pautar o seu poder de conformação do procedimento administrativo. Não se lhe exige nem que seja temerosa (mas expedita) nem complexa (mas econômica) nem "picuinhas" ou burocrática (mas eficiente). E nisto, da desburocratização e eficiência, vai sintetizado muito da essência do procedimento administrativo, como vectores fundamentais que são do princípio da informalidade ${ }^{22}$.

Passando-se à Espanha, tem-se que a Constituição de 1978, no seu art. 103.1, logo após declarar que a Administração Pública serve com objetividade aos interesses gerais, afirma que aquela atua de acordo com vários princípios, dentre os quais o da eficácia.

Examinando o alcance do preceptivo magno, Luis Cosculluela Montaner ${ }^{23}$ alude a que as consequiências do maltrato à eficácia somente são capazes de produzir efeitos no que concerne à exigência de responsabilidade política do Governo ante o Parlamento. Todavia, o próprio autor, em visão crítica, adianta que tal deveria importar ainda à cessação dos efeitos das nomeações efetuadas discricionariamente pelo Governo, à responsabilidade disciplinar dos servidores e também à responsabilização civil da Administração.

A exemplo da confusão terminológica já verificada quando da referência ao direito português, o princípio da eficácia se complementa com o da eficiência, referido no art. 3.2 da Ley 30, de 26 de novembro de 1992, relativa ao Regime Jurídico das Administrações Públicas e ao Procedimento Administrativo Comum (LRJ-PAC), restrito a uma relação adequada de gasto frente ao serviço a ser prestado.

Por seu turno, Ernesto García Trevijano ${ }^{24}$, examinando o art. 103.1 da Lei Maior de 1978, propõe o seguinte entendimento: os princípios de hierarquia, descentralização, desconcentração e coordenação, também referidos no mencionado preceptivo, não são nada caso não se projetem em direção à finalidade a alcançar, qual seja uma atuaçãr) eficaz da Administração. Afirma, então, que o princípio da eficácia seria o objetivo a ser perseguido, enquanto os demais não passam dos meios com os quais aquele será obtido.

21 Códizo do Procedimento Administrativo anotado. 3. ed. Coimbra: Almedina, 1998. p. 53.

22 Código do Procedimento Administrativo. 2. ed. Coimbra: Almedina, 1999. p. 132. Note-se que nesta última apreciação o significado de eficiência é dissociado do emprego contido de meios à disposição do órgão, o qual passa a relacionar-se ao objetivo de economia, referido no art. $10^{\circ}$ do Decreto-lei 442/91, passanito a aproximar-se da desburocratização no decidir.

23 Manual de derecho administrativo. 7. ed. Madri: Civitas, 1996. p. 171.

24 Constitución espcinola - Sinopsis artículo 103. Disponível em: www.congreso.es. Acesso em: 22 mar 2005. 
Assim, a hierarquia, que se põe em conexão com a estrutura interna de cada Administração Pública, delimitando competências, inclusive com o uso de técnicas como a avocação e a delegação, constitui instrumento útil para apanhar-se uma maior eficácia no atuar administrativo. O mesmo quanto à descentralização e a desconcentração, sem contar a utilidade da coordenação, a demonstrar a necessidade dos diversos órgãos das Administrações Públicas atuarem de forma conectada e coerente, evitando conflitos de competências, e caminhando para uma otimização de sua atividade.

Ultimando suas observações, expõe o autor que uma das mais destacadas manifestações do princípio da eficácia se encontra no privilégio de autotutela e de executividade dos atos administrativos, previstos nos arts. 56 e 57 da Ley 30/1992.

Antes do encerramento deste tópico, proveitosa a remissão à ordem jurídica vigente na Argentina, país latino-americano, em cuja doutrina os termos eficácia e eficiência não representam novidade.

Roberto Dromi ${ }^{25}$ utiliza como equivalentes os termos eficácia e eficiência, erigindo-os como um dos novos valores do direito contemporâneo, a partir da premissa de que a sociedade repudia a volta a um Estado ineficiente, ao aspirar, como legítima reivindicação, a garantia da eficácia do atuar de toda a organização administrativa.

Reportando-se à eficácia, o autor a identifica com a administração racional do bem-estar geral, com a exclusão de uma administração passional, influenciada de legalismo e com estruturas burocráticas excessivas e obsoletas. Para sua consolidação, aponta como necessário o prestígio constitucional, de modo a obter-se a ampliação da participação política e social (arts. 37 a 40 e 42), a garantia do equilíbrio dos poderes, a eficiência da legislação (arts. 63, 76 e 82) e da jurisdição (arts. 108, 114 e 120), a consolidação da reforma do Estado (art. 42 , parágrafo $2^{\circ}$ ), a recriação do controle do poder (arts. 42, parágrafo $3^{\circ}, 53,85$ e 86, 101, 114, incs. 4 e 5,115 e 120), o estabelecimento da descentralização (arts. 123 e 124), o instrumentar da regionalização interior (arts. 75, inc. 19 e 124) e a integração dos países (art. 75, inc. 24$)^{26}$.

Quanto à eficiência, Dromi a reputa como

um requisito vital, pois vai implicitamente ligada a cláusulas do progresso tradicional da sociedade (art. 75, inc. 18), e as cláusulas do novo progresso educativo, cultural, tecnológico, pessoal, científico e humano que deve procurar a comunidade (art. 75, inc. 19). Vai intimamente vinculada à prontidão, à celeridade nos afazeres dos encargos públicos e à transparência da atuação governativa (art. $36,6^{\mathbf{a}}$ parte) ${ }^{27}$.

25 Derecho administrativo. 5. ed. Buenos Aires: Ciudad Argentina, 1996. p. 26.

26 Os artigos entre parêntesis integram o texto da Constituição da Nação Argentina de 1853, com a redação ofertada pela reforma de 22 de agosto de 1994.

27 “...un requisito vital, pues va implícitamente ligada a lãs cláusulas del progreso tradicional de la sociedad (art. 75, inc. 18) y a cláusulas Del nuevo progreso educativo, cultural, tecnológico. 
Afora tais observações, extraídas de uma visão de conjunto da Constituição Nacional, não se pode esquecer que a Ley 19.549, de 03 de abril de 1972, ao disciplinar o procedimento administrativo, traz à baila a imposição de eficácia nos seus trâmites (art. $1^{\circ}$, alínea $b$ ).

Procurando desvendar a acepção colimada pelo legislador para eficácia, Julio Rodolfo Comadira ${ }^{28}$, após realçar a sua não confusão com ativismo administrativo inescrupuloso e displicente respeito da juridicidade, aponta para a busca à introdução de técnicas não tradicionais para a atuação administrativa, como são as modalidades de manifestação negocial ou acordada com os interessados, das quais se origina o término convencional do procedimento administrativo ${ }^{29}$.

\section{O significado e a natureza da eficiência administrativa.}

Feita alusão aos modelos legislativos estrangeiros, passemos à tarefa, árdua por sinal, de demarcação semântica do que se deve entender por eficiência.

A preocupação, que também permeou a doutrina de fora destas plagas, encontrou ressonância na pena de Sandulli $^{30}$ que, desvelando as diversas ramificações do postulado do bom andamento, oferta relevo à economicidade, à eficácia e à eficiência como categorias distintas e autônomas.

personal, científico y humano que debe procurar la comunidad (art. 75, inc. 19). Va intimamente vinculada a la prontitud, a la celeridad em el quehacer de los cometidos públicos y la transparência del hacer gubernativo (art. 36, 6a. parte)". (Derecho administrativo. 5. ed. Buenos Aires: Ciudad Argentina, 1996. p. 27).

28 Procedimientos administrativos - Ley Nacional de procedimientos administrativos anotada y comentada. Buenos Aires: La Ley, 2003. Tomo I, p. 65-66. A mesma exposição consta noutra obra (Derecho administrativo 2 . ed. Buenos Aires: Abeledo-Perrot, 2004. p. 148-149).

29 A inquietação com o proceder eficiente do administrador da coisa pública se manifesta noutras vigentes constituições, tais como a: a) da República do Chile, cujo art. 38, à conta de estatuir as bases gerais da Administração do Estado, propõe que a carreira funcional se guie pelos princípios de caráter técnico e profissional em que deva fundar-se, com a garantia do mérito no seu ingresso, juntamente com a capacitação e o aperfeiçoamento de seus integrantes; b) mexicana, ao prever, no seu art. 112, que a lei disciplinará as responsabilidades administrativas dos servidores públicos, bem como determinará "suas obrigaçōes, a fim de salvaguardar a legalidade. honradez, lealdade, imparcialidade e eficiência no desempenho de suas funções, empregos, cargos e comissões". (sus obligaciones a fin de salvaguardar la legalidad, honradez, lealtad, imparcialidad y eficiência en el desempeño de sus funcones, empleos, cargos y comisiones". Disponível em: www.baja.com. Acesso em: 03 jul. 2003. Tradução livre); c) Constituição Federal da Confederação Suíça que, no seu art. 178, dedicado à Administração Federal, dispõe: "O Governo Federal deverá dirigir a Administração Federal. Deverá garantir sua organização eficiente e o efetivo cumprimento de suas tarefas" (The Federal Government shall direct the Federal Administration. It shall ensuere its efficient organization and the effective fulfillment of the tasks". Disponível em: www.swissemb.org/leal/const.pdf. Acesso em: 25 maio 2004. Tradução livre).

30 Il procedimento. In: CASSESE, Sabino (Coord.). Trattato di diritto amministrativo - Diritto amministrativo generale. Milão: Dott. A. Giuffrè Editore, 2000. Tomo secondo, p. 976-7. 
Após dizer que tais conceitos possuem uma derivação de natureza econômica, afirma que a economicidade impõe à Administração Pública o dever de empregar um adequado uso dos recursos à sua disposição. Por sua vez, eficácia exprime a necessidade de que a administração ponha em movimento uma ação idônea à obtenção de um determinado resultado. Já a eficiência reclama, com referência à manifestação do sujeito administrativo, o balanço entre os custos despendidos $\mathrm{e}$ as vantagens alcançadas, cabendo a existência de saldo favorável a estas últimas (balanço e custo-benefício).

Apesar de o autor apontar para a caracterização de três conceitos autônomos, verifica-se, sem sombra de dúvidas, a aproximação entre o compreendido por economicidade (utilização adequada de recursos) e eficiência (balanço e custo-benefício), esta abarcando a primeira.

Entre nós, Ubirajara Custódio Filho ${ }^{31}$, ao depois de referir-se que, no sentido comum, eficiência é de ser tida como sinônimo de eficácia, ou seja, de algo com qualidade capaz de produzir bons resultados, que funciona de acordo com o padrão esperado, ou, pelo menos, aceitável ${ }^{32}$, esclarece, no particular do seu significado científico, peculiar à ciência da administração, encontrar-se aquela voltada para o ótimo aproveitamento dos recursos disponíveis, com abstração da responsabilidade pelo cumprimento de metas.

Feita essa distinção, propende que o vocábulo eficiência, atualmente figurante do elenco do art. 37, caput, da Constituição, deve ser interpretado com base no sentido comum, alinhando, para dar suporte a tal opinião, quatro razões, alicerçadas no princípio da máxima efetividade do texto constitucional, nos aspectos teleológico e sistemático da norma interpretada e, finalmente, no princípio da indisponibilidade do interesse público.

Rematando, o autor visualiza no princípio da eficiência o mandamento segundo o qual "a Administração Pública deve atender o cidadão na exata medida da necessidade deste e com agilidade, mediante adequada organização interna e ótimo aproveitamento dos recursos disponíveis" ${ }^{33}$.

Apesar da preferência pela significação comum de eficiência, observa-se, de logo, que dita conceituação, na realidade, é obtida da simbiose entre aquela e a noção científica de eficiência. Basta que se note a referência ao melhor aproveitamento dos meios que se acham à disposição do administrador.

31 A Emenda Constitucional 19/98 e o princípio da eficiência na administração pública. Cadernos de Direito Constitucional e Ciência Política. São Paulo, n. 27, ano 7, p. 211-214, abr./jun. 1999.

32 Rápido compulsar do dicionário de Aurélio Buarque de Holanda Ferreira (Dicionário Aurélio Eletrônico, versão 2.0, Editora Nova Fronteira, 1996) atribui ao verbete eficiência, afora outros significados particulares, o de "ação, força, virtude de produzir um efeito; eficácia".

33 A Emenda Constitucional 19/98 e o princípio da eficiência na administração pública. Cadernos de Direito Constitucional e Ciência Política. São Paulo, n. 27, ano 7, p. 211-214, abr./jun. 1999. 
Nota-se, igualmente, uma certa identificação do pensamento acima com a lição estrangeira, ministrada por Sandulli, a qual, como visto linhas atrás, engloba sob o pálio da eficiência (relação entre custos despendidos versus vantagens obtidas) tanto a economicidade (emprego racional dos recursos disponíveis) quanto ao que denomina de eficácia (ação voltada à busca de determinados resultados) ${ }^{34}$.

Esse estuque doutrinário serve como bússola para que se possa, com solidez, aportar numa cristalina concepção do postulado da eficiência. Assim este deverá ser compreendido como o dever administrativo de melhor atender à consecução dos fins, de interesse público, a que está vinculada a Administração, laborando, para tanto, com o menor custo. Fica, de logo, acentuado que eficiência compreende a vinculação do administrador à economicidade ${ }^{35}$, referida no art. 70, caput, da $\mathrm{CF}$.

Essa exigência impõe, como ressaltado por Ubirajara Custódio Filho ${ }^{36}$, uma atuação com prestabilidade, fornecendo-se aos cidadãos prestações que possuam utilidade, com presteza, a implicar atendimento com rapidez, e do modo menos oneroso possível ao erário público, isto é, com economicidade.

Para esse fim, mostrar-se-á relevante, entre outras, a exigência de alguns parâmetros, tais como o que reclama uma atuação média do aparato administrativo, o desenvolvimento salutar de praxes administrativas, a manifestação simplificada da vontade da Administração e a resolução de conflitos por mecanismos consensuais.

Delineado, com a precisão possível, o conteúdo do princípio da eficiência administrativa, interessa saber a sua natureza.

Demais de traduzir-se num valor, interessante averiguar se aquele se cuida de princípio jurídico, dada a sua forte imbricação com a ciência da administração ou economia.

Isso tem gerado uma certa perplexidade na doutrina. Por exemplo, Egon Bockman Moreira ${ }^{37}$ manifesta que a EC $19 / 98$ pretendeu imputar à Administração Pública uma máxima não-jurídica, pertinente à administração e à economia, típica cia atividade de entidades privadas.

34 Não diferente, Mateus Eduardo Siqueira Nunes Bertoncini (Princípios de direito administrativo brasileiro. São Paulo: Malheiros Editores, 2002. p. 122-123) também aponta que a percepção do princípio da eficiência perpassa, inelutavelmente, pela relação entre meios e resultados, vista no conjunto dos demais princípios e regras administrativas. Já Paulo Modesto (Notas para um debate sobre o princípio da eficiência. Revista Trimestral de Direito Público. São Paulo, n. 31, p. 48-49, mar. 2000) expõe que tal cânon possui duas dimensões, consistentes na racionalidade e otimização no uso dos meios e na satisfatoriedade de resultados da atividade administrativa pública.

35 Sobre economicidade, sugere-se a leitura de Márcia Filomena de Oliveira Mata (Fiscalização da Administração Pública em face da economicidade. Revista dos Tribunais. São Paulo, v. 710, p. 233-236, dez. 2004).

36 Ob. cit. p. 214.

37 Processo administrativo e princípio da eficiência. In: SUNDFELD, Curlos Ari e ANDRÉS MUÑOZ, Guillermo (Coord.). As leis de processo administrativo - Lei Federal 9.784i99 e Lei Paulista 10.177/98. São Paulo: Malheiros Editores, 2000. p. 325. 
Um pouco adiante, afirma incisivo: "Conforme já mencionado, não se trata de princípio jurídico, muito menos poderia ser alçado à condição de norma constitucional. Sua inserção não gerará nenhuma novidade ou benefício concreto" ${ }^{38}$.

Muito embora não sustente a ausência de juridicidade da eficiência administrativa, Celso Antônio Bandeira de Mello reduz demasiadamente a sua densidade sob o aspecto em comento, sentenciando que aquele "é juridicamente tão fluído e de tão difícil controle ao lume do Direito, que mais parece um simples adorno agregado ao art. 37 ou o extravasamento de uma aspiração dos que burilam no texto" 39 .

Um certo desdém igualmente é notado em Jessé Torres Pereira Júnior, ao anotar que a inscrição da eficiência entre os princípios dirigentes da atividade administrativa "só se pode compreender como uma figura de estilo, um reforço de linguagem para enfatizar o que é inerente à Administração Pública e é dela reclamado pelos administrados" 40 .

Outra corrente da doutrina, que se tem por numerosa, sustenta a configuração da eficiência administrativa como lídimo princípio integrante do sistema jurídico administrativo.

Paulo Modesto ${ }^{41}$, mesmo não se omitindo em salientar que o termo "eficiência" não se apresenta como privativo de um determinado ramo científico, a sua apropriação pelo legislador fez com que o mesmo não mais fosse percebido sob os prismas meramente políticos ou econômicos, passando a constituir uma pauta de comportamento exigível do administrador para a validade e legitimidade da ação estatal.

Já Emerson Gabardo ${ }^{42}$ é esclarecedor que, demais de nenhum princípio nascer eminentemente jurídico, ontologicamente considerado, a sua etimologia independe de qualquer conotação intrinsecamente econômica, referindo-se a uma atividade racional, destinada a encontrar os melhores meios para a obtenção otimizada dos fins almejados. Em segundo lugar, sustém que, ainda que se estivesse na presença de um conceito, intrínseca e inafastavelmente econômico, haveria a privação de tal significado quando de sua absorção pela ordem jurídica.

Grande parcela dos autores nacionais já se vem inclinando pela consideração da eficiência como princípio do direito administrativo, podendo-se, à laia de exemplo, indicar Odete Medauar ${ }^{43}$, Maria Sylvia Zanella di Pietro ${ }^{44}$, Vladimir da Rocha

38 Ob. cit., p. 326.

39 Curso de direito administrativo. 15. ed. São Paulo: Malheiros Editores, 2003. p. 112.

40 Da reforma administrativa constitucional. Rio de Janeiro: Renovar, 1999. p. 41.

41 Notas para um debate sobre o princípio da eficiência. Revista Trimestral de Direito Pública.

São Paulo, n. 31, p. 48-49, mar. 2000.

42 Princípio constitucional da eficiência administrativa. São Paulo: Dialética, 2002. p. 91.

43 Direito administrativo moderno. 3. ed. São Paulo: Revista dos Tribunais, 1999. p. 145.

44 Direito administrativo. 18. ed. São Paulo: Atlas, 2005. p. 84-85. 
França $^{45}$, Ruy Samuel Espíndola ${ }^{46}$, Mateus Eduardo Siqueira Nunes Bertoncini ${ }^{47}$, Dalton Santos Morais ${ }^{48}$, Alzemeri Martins ${ }^{49}$ e Joel de Menezes Niebuhr ${ }^{50}$.

Penso que a última corrente possui integral razão. A qualidade de princípio jurídico portada pela eficiência está em que o seu conteúdo é vinculativo aos órgãos públicos.

Daí que a legitimidade da prática está jungida à realização de uma finalidade eficiente, que produza resultados satisfatórios no atendimento do interesse público.

A sujeição dos órgãos estatais à eficiência é de visualização singular na pena de Ruy Samuel Espíndola, para quem aquela não constitui apenas modelo a ser alcançado pela manifestação dos atos administrativos, mas, ao invés, critério para a elaboração das normas que disponham sobre o funcionamento da Administração. Para o autor, as

leis que criem entraves à eficiência, que burocratizem desmedidamente o serviço público, desatendendo à racionalidade necessária à boa consecução do serviço, poderão ser invalidadas nas vias do controle de constitucionalidade, por inconstitucionalidade material, por malferimento ao princípio constitucional da eficiência ${ }^{51}$.

Essa conclusão, cujo acerto parece ser procedente, serve para mostrar a forte densidade do liame entre a eficiência e a atuação estatal.

45 Eficiência administrativa na Constituição Federal. Revista dos Tribunais. São Paulo, ano 89, v. 777 , p. 747 , jul. 2000.

46 Princípios constitucionais e atividade jurídico-administrativa: anotações em torno de questões contemporâneas. In: LEITE, George Salomão (Coord.). Dos princípios constitucionais - considerações em torno das normas principiológicas da Constituição. São Paulo: Malheiros Editores, 2003. p. 283-284.

47 Principios de direito administrativo brasileiro. São Paulo: Malheiros Editores, 2002. p. 123.

48 Os custos da atividade administrativa e o princípio da eficiência. Revista de Direito Adminis. trativo. Rio de Janeiro, n. 237, p. 182, jul./set. 2004.

49 A norma principiológica da eficiência numa abordagem prefacial relativamente desapaixonada. JAM - Jurídica Administração Municipal, v. 5, n. 1, p. 1-6, jan. 2000.

so Princípio da eficiência: dimensão jurídico-administrativa. Jurídica Administração Municipal, ano IV, n. 9, p. 14-18. O trato da questão, na península itálica, foi alvo de descrição por parte de Sandulli 11 procedimento. In: CASSESE, Sabino (Coord.). Trattato di diritto amministrativo Diritto amministrativo generale. Milão: Dott. A. Giuffrè Editore, 2000. Tomo secondo, p. 958), o qual noticiou que, no primeiro decênio da Constituição de 1947, os intérpretes do art. 97 vislumbravam a imparcialidade e o bom andamento como algo privado de conteúdo jurídico, estando circunscritas à organização administrativa, de modo que somente a partir da década de sessenta que fora adquirida plena consciência do valor preceptivo de tais princípios.

51 Princípios constitucionais e atividade jurídico-administrativa: anotações em torno de questões contemporâneas. In: LEITE, George Salomão (Coord.). Dos princípios constitucionais - considerações em torno das normas principiológicas da Constituição. São Paulo: Malheiros Editores, 2003. p. 284. 
Além do mais, o fato da eficiência ostentar fortes pontos de contato com as ciências da administração e econômica não afasta, só por só, o seu caráter de princípio integrante do sistema jurídico. Absolutamente. Lembrando-se a lição de Rivero, citada no primeiro tópico deste trabalho, há princípios do direito administrativo que resultam da vinculação do administrador às exigências da vida coletiva, ensinamento que, com o passar do tempo, vem granjeando uma maior admissibilidade na doutrina, como se pode notar de referência a Jean Michel de Forge ${ }^{52}$. A eficiência é, estreme de dúvida, um padrão de conduta que resulta particularmente indispensável ao nosso tempo e que, por isso, não pode ser postergada pela Administração.

Demonstração inequívoca da eficiência como princípio de direito administrativo é ofertada ainda pelos inúmeros julgados que, recentemente, vêm procedendo à sua invocatória como fundamento de solução de litígios entre o cidadão e a Administração Pública, os quais serão objeto de menção doravante.

4. A positivação do princípio da eficiência no direito brasileiro antes e depois da Emenda Constitucional 19/98

Neste tópico, deve-se, primeiramente, desfazer-se um equívoco, qual seja de que a imposição de eficiência administrativa adveio com a EC 19/98.

Aquela, contrariamente, precede, em muito, a mencionada reforma constitucional.

Prova insofismável disso é que Carvalho Simas, em escrito elaborado sob a égide da Constituição de 1969, punha em destaque a eficiência como um dos princípios norteadores da Administração Pública, evocando o ensinamento da doutrina itálica do dever de boa administração. Foram suas palavras:

A ação dos administradores deverá apresentar, como resultado, uma efetiva satisfação das necessidades coletivas. No conceito apresentado de 'função administrativa' está implícito o real atendimento dessas necessidades, o que só poderá ser alcançado através de uma atuação adequada e positiva dos órgãos e agentes do Governo. (...) Ao lado da estrita observância dos princípios da legalidade e da moralidade, a Administração Pública não poderá ser ineficiente. É inaceitável que sua atuação apresente, como resultado, a falta de atendimento àquelas solicitações gerais, que está obrigada a satisfazer. Os agentes e órgãos do Poder Público têm o dever de bem servir, dentro da moralidade administrativa, mas diligenciando para apresentar, pelo emprego de processos e técnicas apropriadas, um saldo proveitoso ${ }^{53}$. 
Igualmente escrevendo com precedência à Lei Maior de 1988, Hely Lopes Meirelles ${ }^{54}$ aludiu ao dever de eficiência, imposto aos agentes públicos, no sentido destes realizarem suas atribuições com presteza, perfeição e rendimento funcional.

O ponto de partida da positivação de dito princípio coube ao legislador infraconstitucional, especificamente ao Decreto-lei 200, de 25 de fevereiro de 1967, que estabelecera diretrizes para reforma da Administração Pública Federal.

A preocupação com a eficiência, em referido diploma, constituiu nota constante e de relevo. Principiando-se pelo seu art. 13, verifica-se a preocupação com o controle das atividades da Administração Federal, a ser exercido em todos os níveis e em todos os órgãos, compreendendo a execução dos programas, das normas que disciplinam a atividade específica do órgão controlado, da aplicação do dinheiro público e guarda dos bens da União.

Mais adiante, tem-se, com relação às entidades componentes da Administração Indireta, o controle finalístico, denominado de supervisão ministerial (art. 25), a qual visa assegurar, essencialmente, a eficiência administrativa (art. 26, III).

No que concerne ao pessoal do serviço público civil, o art. 94, II, III e V, do Decreto-lei 200/67 trouxe o compromisso de ajustamento da respectiva legislação, com o objetivo de conformá-la à consecução de determinadas metas, muitas das quais intimamente ligadas à busca de uma gestão eficiente, como o aumento de produtividade, a profissionalização e aperfeiçoamento do serviço público, fortalecimento do sistema de mérito no acesso à função pública e na escolha dos ocupantes das funções de direção e assessoramento, constituição de quadros dirigentes mediante a formação e aperfeiçoamento de administradores capacitados a garantir a qualidade, produtividade e continuidade da ação governamental.

Como se não bastasse, o art. 101 do mencionado diploma, com a redação do Decreto-lei 900/69, previra, para pânico dos mais ardorosos defensores da Administração Pública patrimonialista, que o provimento dos cargos em comissão e funções gratificadas deverá obedecer critérios fixados em atos do Poder Executivo, o qual, afora a definição do campo de livre escolha do Presidente da República, estabelecerá os piocessos de recrutamento com base no sistema de mérito.

A própria redação originária da Lei Maior vigente, no seu art. 74 , II, ao tratar do sistema de controle interno, previu que este possui a finalidade de comprovar a legalidade e avaliar os resultados da gestão orçamentária, financeira e patrimonial da Administração Federal, no que concerne à eficácia e à eficiência ${ }^{55}$.

Volvendo-se ao plano legislativo, a Lei 8.987, de 13 de fevereiro de 1995 , assentou, a pretexto de disciplinar o regime de permissão e concessão de serviços públicos, no seu art. $6^{\circ}$, caput, e $\S 1^{\circ}$, o encargo de prestação de serviço adequado, considerado aquele que cumpre as condições de regularidade, continuidade, eficiên-

54 Direito administrativo brasileiro. 12. ed. São Paulo: Revista dos Tribunais, 1986. p. 69.

55 Não esquecer o art. $144, \$ 7^{\circ}$, da $\mathrm{CF}$, ao dispor que a lei disciplinará a organização e o funcionamento dos órgãos responsáveis pela segurança pública, serviço afeto à função administrativa, de maneira a garantir a eficiência de suas atividades. 
cia, segurança, atualidade, generalidade, cortesia na sua prestação e modicidade das tarifas.

A eficiência, sem dúvida, foi, antes da EC 19/98, erigida como padrão obrigatório na prestação dos serviços públicos.

Esse o cenário normativo vigorante quando $S$. Exa., o então Presidente Fernando Henrique Cardoso, entendendo imprescindível a implantação de modelo gerencial administrativo em substituição ao burocrático, adequado apenas à satisfação das necessidades públicas no Estado Liberal, encaminhou ao Congresso Nacional proposta de emenda constitucional, cuja sustentação teórica se louvou no Plano Diretor da Reforma do Aparelho do Estado ${ }^{56}$, de novembro de 1995.

Promulgada a Emenda Constitucional 19, de 05 de junho de 1998, acrescentouse ao rol de princípios do art. 37, caput, da Lei Básica, a menção à eficiência.

Trouxe a vasta emenda duas previsões tendentes a desenvolver referido postulado. A uma, legou novo teor ao $\$ 3^{\circ}$ do art. 37 , mencionando competir à lei disciplinar as formas de participação do usuário na Administração Pública Direta e Indireta, regulando-se, especialmente, as reclamações decorrentes da prestação de serviços públicos, com vistas a assegurar a manutenção de serviços de atendimento ao usuário e a avaliação periódica, externa e interna, da qualidade dos serviços.

Em segundo lugar, aditou-se ao rol de situações que respaldam a quebra da estabilidade dos servidores públicos efetivos, previsto no art. 41 , o inciso III, contemplando procedimento de avaliação periódica de desempenho, no qual seja ao interessado assegurada ampla defesa, devendo ser estabelecidos critérios e garantias especiais aos exercentes de atividades exclusivas de Estado (art. 247), o que, a bem da verdade, seria de todo dispensável caso tivesse logrado aplicação o art. 100 do Decreto-lei 200/67.

Com o elogiável propósito de aferição dos gastos públicos frente aos resultados da atividade administrativa, adveio a Lei Complementar 101, de 04 de maio de 2000, contendo normas de finanças públicas dirigidas à responsabilidade fiscal, em cujo art. 67, II, restou prescrito que o acompanhamento e a avaliação da política e da operacionalidade da gestão fiscal seria realizada visando à disseminação de práticas que resultem maior eficiência na alocação e execução do gasto público, na arrecadação de receitas, no controle do endividamento e na transparência da gestão fiscal.

De verificar-se, então, que o princípio da eficiência se encontra em demasia positivado no sistema jurídico brasileiro, seja anterior ou posteriormente à EC 19/98. Essa circunstância implica o condicionamento do atuar estatal a um novo modelo de agir, acarretando consequêencias no perfil de vários institutos administrativos, cujo impacto surge interessante averiguar.

56 A íntegra do documento pode ser obtida em www.planalto.gov.br/publi_04. Nele está consignado - com máxima justiça - que o Decreto-lei 200/67 constituíra um marco na tentativa de superação da rígida concepção burocrática, pudendo ser considerado como o primeiro instante da administı ação gerencial nestas plagas. Entretanto, tal reforma não alcançou as mudanças esperadas, tendo em vista a coexistência de núcleos de eficiência e competência na Administração Indireta ao lado de formas arcaicas e ineficientes na Administração Direta. 


\section{O princípio e sua influência nos institutos administrativos.}

O primeiro reflexo da eficiência condiz com os atos administrativos, a recomendar que estes, na condição de decisões tomadas pela Administração, produzam seus efeitos da maneira mais eficiente possível. Somente assim estar-se-á atendendo ao interesse público.

A jurisprudência nos fornece exemplos da influência do atuar eficiente na tomada de decisões administrativas. O Supremo Tribunal Administrativo português, no Proc. $n^{\circ} .41 .027^{57}$, relacionado com concurso de recrutamento funcional, considerando tanto que esta opção, ao invés de procedimento de escolha, cumpria o objetivo de optimização do direito de acesso a cargos públicos, salientou que, na omissão de aviso de abertura, o termo final para a manifestação dos interessados deveria recair na data em que a correspondência fosse confiada à repartição postal, ao contrário daquela do seu recebimento no órgão próprio, uma vez a primeira opção ser mais consentânea com a finalidade do procedimento escolhido. $\mathrm{Na}$ assentada, consignou-se que a eficiência, na qualidade de fator de interpretação dos atos administrativos, há de presumir a racionalidade e a maximização dos procedimentos adotados.

De igual forma, homenageou o princípio da eficiência a $6^{\mathbf{a}}$ Turma do Tribunal Regional Federal da $1^{\text {s }}$ Região $0^{58}$, ao censurar ato de presidente de comissão de concurso para o cargo de Professor Assistente da Universidade Federal do Piauí que, mesmo diante do provimento, pelo Conselho Departamental do Centro de Ciências da Educação, de pedido de reconsideração, formulado contra o indeferimento de inscrição, impedira o impetrante de realizar as avaliações, tendo em vista a ausência de comunicação da decisão administrativa que aceitara sua inscrição. A falha em não cientificar o impetrado conspirou em detrimento da produção dos efeitos inatos ao ato atributivo de vantagem ao impetrante, evidenciando inadmissível ineficiência.

Não esquecer também a necessidade, imposta à Administração, de adequar-se, nas suas atuações, às exigências reclamadas pela modernidade, imprimindo-lhes um caráter de maior dinamicidade. A utilização dos recursos da informática torna-se, assim, um imperativo de observância obrigatória pelos atuais administradores.

Atento a essa preocupação, o Superior Tribunal de Justiça, ao desatar o REsp 492.141 - SC ${ }^{59}$, corroborou o acerto decorrente da modificação imposta pela Lei 9.532/97 ao art. $15, \S 2^{\circ}$, do Decreto-lei n. $1.510 / 76$, ao estatuir a obrigatoriedade da apresentação, pelos titulares de serviços notariais, de Declaração de Operações Imobiliárias em meio magnético, respaldando a recusa, pela repartição fiscal, da entrega de declarações datilografadas. Acentuou, com muita propriedade, o relator:

Ora, a recorrida entregou as declarações em forma diversa da exigida datilografadas. É certo que a Lei busca a entrega das declarações. No entanto,

57 I*. Subseção do CA, ac. un., Rel. Victor Gomes, julg. em 30-04-98.

58 REOMS 2002.40.00.001991 - PI, ac. un., rel. Juiz Moacir Ferreira Ramos, julg. em 08-03-2004.

s9 1*. T., ac. un., rel. Min. Humberto Gomes de Barros, DJU de 15-12-2003. 
quer que a comunicação seja feita 'em meio magnético aprovado pela Secretaria da Receita Federal.' (DL 1.510/76, § $1^{\circ}$, art. 15, acrescentado pela Lei 9.532/97). Neste caso, o intuito é colocar a Administração na Era da Informática, modernizando o procedimento administrativo, acrescentandolhe celeridade, economia e eficiência.

Nessa linha, há uma atraente proposta, formulada por Marcus Vinícius Filgueiras Júnior ${ }^{60}$, favorável à permissibilidade do ato administrativo editado por meio eletrônico. Ao depois de frisar a estreiteza entre informática e o princípio constitucional da eficiência, arrola um sem-número de vantagens da utilização daquela na prática das condutas administrativas, mais especificamente quanto à adoção do ato administrativo em forma eletrônica, podendo, por apego à concisão, ser enunciadas a total possibilidade de automatizar os denominados atos vinculados e diminuir as situações de equívoco acerca da competência dos agentes públicos. Conclui, igualmente, pela possibilidade, diante do ordo juris, da atual validade dos atos administrativos mediante documentos eletrônicos, contanto que emitidos pelo sistema ICP - Brasil, como autorizado pela Medida Provisória 2.200/01 (art. 10, § 1 $\left.{ }^{\circ}\right)^{61}$.

Outro ponto a ser destacado é que, considerando os esforços despendidos pela máquina administrativa para tomar suas decisões, não se pode esquecer, em homenagem ao princípio da eficiência, a necessidade de aproveitamento daquelas quando passíveis de irregularidades sanáveis, ou quando ocorrer alguma barreira ao dever de invalidar ${ }^{62}$. Daí os institutos da convalidação e da impossibilidade de invalidação pelo transcurso do tempo, aliado à boa-fé, previstos na Lei 9.784/99 (arts. 54 e 55), ocupando-se de consequêencias com derivação no postulado em estudo ${ }^{63}$.

Também é notável a influência do princípio na licitação. Demais de garantir-se a isonomia, com o acesso a todos os que possuam condições de atender às necessidades públicas, tem-se como fim não menos importante de dito procedimento o de propiciar à Administração, de maneira eficiente, a definição do objeto a ser contra-

60 Ato administrativo eletrônico e teleadministração. Perspectivas de investigação. Revista de Direito Administrativo. Rio de Janeiro, v. 237, 261-262, jul./set. 2004.

61 O dispositivo possui a seguinte dição: "Art. 10. Consideram-se documentos públicos ou particulares, para todos os fins legais, os documentos eletrônicos de que trata esta Medida Provisória. $\S 1^{\circ}$ As declarações constantes dos documentos em forma eletrônica produzidos com a utilização de processo de certificação disponibilizad’ pela ICP - Brasil presumem-se verdadeiros em relação aos signatários, na forma do art. 131 da Lei 3.071, de $1^{\circ}$ de janeiro de 1916 - Código Civil".

$62 \mathrm{O}$ aspecto enfocado guarda correlação com o decidido na REOMS 2000.01.00.005382-7 DF (TRF - 1" Reg., 1" T., ac. un., rel. Juiz Luciano Tolentino do Amaral, julg. em 25-04-2000), no qual se frisou, com base na eficiência, que a competência de invalidação dos atos administrativos não poderia respaldar a reprovação por falta de aluno, aplicada no momento em que requerera declaração de conclusão de curso, uma vez já tido como aprovado na disciplina há dois anos.

63 Não é por outra razão que Germana Moraes (Obrigatoriedade de motivação explícita, clara, congruente e tempestiva dos atos administrativos. Interesse Público, ano 2, vol. 8, p. 52, out. 2000), fundada no princípio da eficiência, propõe a amenização da legalidade, com a recomendação do aproveitamento, quando for possível, dos atos administrativos editados com vício de motivação. 
tado e as melhores condições para a seleção da proposta que melhor satisfaça ao interesse público. Para tanto, de muita valia a observância da regra do julgamento objetivo e a análise das propostas inexequíveis ou que contenham preço superior ao praticado (arts. 45 e 48, Lei 8.666/93). Idem a indispensabilidade de motivação nas hipóteses de dispensa e inexigibilidade da competição (art. 26, parágrafo único, Lei 8.666/93).

O dever de eficiência se estende ao posterior contrato, tanto que a execução deste deverá guardar fidelidade às cláusulas estipuladas, cabendo ao Poder Público exercer o devido acompanhamento e fiscalização para que o interesse público não seja afetado.

Essa preocupação esteve presente no julgamento do REsp $144.750-\mathrm{SP}^{64}$, ao sublinhar-se a legitimidade da exigência em concorrência, instaurada pela Telecomunicações de São Paulo S/A, para execução de serviços de rede externa (construção de galerias de dutos e caixas subterrâneas), de apresentação, pelas empresas licitantes, de atestados técnicos emitidos por concessionária de serviço público.

A atividade inerente ao poder de polícia, mais recentemente denominada de administração ordenadora, não poderá dissociar-se da eficiência. Isso porque a limitação de direitos e atividades não poderá ser tão intensa que elimine a essência da liberdade individual, devendo, ao invés, restringir-se ao estritamente necessário à garantia do bem-estar geral.

A proporcionalidade, que governa tal competência administrativa, reclama a adoção de instrumentos eficientes para a restrição de direitos, evitando-se ações inadequadas e desnecessárias.

O liame entre eficiência e o poder de polícia é bem destacado por Juliano Henrique da Cruz Cereijido, ao acentuar que a não observância daquela "nos atos coercitivos decorrentes do poder de polícia podem trazer agressão tão grande aos direitos e garantias fundamentais, especialmente aos valores da liberdade e da propriedade, os mais afetados pelo exercício de tal limitação administrativa" 65 .

Setor onde o princípio da eficiência talvez se manifeste com maior nitidez é o respeitante aos agentes públicos, até porque é a este que é confiada a gestão da coisa pública. Primeiramente, tal resulta pela imposição de seleção do funcionalismo através do regime de mérito, com a destinação das funções de confiança a servidores ocupantes de cargo efetivo e o estabelecimento de limites para a nomeação de cargos

64 STJ, 1* T., ac. un., rel. Min. Francisco Falcão, DJU de 25-09-2000. A leitura de trecho da ementa se faz oportuna: "É de vital importância, no trato da coisa pública, a permanente perseguição ao binômio qualidade eficiência, objetivando, não só garantir a segurança jurídica do contrato, mas também a consideração de certos fatores que integram a finalidade das licitações, máxime em se tratando daquelas de grande complexidade e de vulto financeiro tamanho que imponha ao administrador a elaboração de dispositivos, sempre em atenção à pedra de toque do ato administrativo - a lei -, mas com dispositivos que busquem resguardar a administração de aventureiros ou de licitantes de competência estrutural, administrativa e organizacional duvidosa".

65 O princípio constitucional da eficiência na Administração Pública. Revista de Direito Administrativo. Rio de Janeiro, n. 226, p. 237, out./dez. 2001. 
em comissão, voltados ao exercício de atribuições de direção, chefia e assessoramento (art. 37, I, II e V, CF).

Em segundo lugar, tem-se a eficiência na execução das tarefas, o que, a nível constitucional, é resguardado pela avaliação periódica de desempenho para fins de conservação da estabilidade (art. $41, \mathrm{III}, \mathrm{CF}$ ), cuja execução ainda não foi posta em prática por falta de integração legislativa.

No que tange à conduta do servidor quanto ao zelo no cumprimento de suas atribuições, de acentuar que a jurisprudência prestigia, sob o pálio da eficiência administrativa, a técnica legislativa em criar gratificações de produtividade, dirigidas para a compensação dos servidores da ativa, sem a extensão, na forma do art. 40 , $8^{\circ}$, da CF, do seu pagamento, no todo ou em parte, ao pessoal inativo ${ }^{66}$.

Ainda no particular da prestação de serviços, demasiado relevante o aprimoramento e capacitação dos servidores, a ser obtido quer mediante diretrizes a serem definidas pelos conselhos de política de administração e remuneração de pessoal, quer pela destinação de recursos orçamentários para serem aplicados no desenvolvimento de programas de qualidade e produtividade, treinamento e desenvolvimento, modernização, reaparelhamento e racionalização do serviço público, sem contar a obrigação da União, Estados e Distrito Federal na manutenção de escolas de governo (art. 39, caput, e $\$ \S 2^{\circ}$ e $\left.7^{\circ}, \mathrm{CF}\right)^{67}$.

No plano infraconstitucional, extrai-se da Lei $8.112 / 90$ a previsão de deveres e proibições funcionais, os quais representam a idéia de eficiência, tais como ser leal às instituições a que servir (art. 116, II). Idem a previsão das situações da pena de demissão (art. 132), entre as quais se sobressaem o abandono de cargo e a inassiduidade habitual.

Exemplo bastante elucidativo do liame entre a postura do servidor público e o princípio em questão nos foi ministrado pela $2^{a}$ SubSecção do Contencioso Administrativo do Supremo Tribunal Administrativo português no Processo 01857/0268. Referido órgão jurisdicional, ao depois de assentar que o dever de zelo funcional é noção tributária da eficiência, assentou a presença de violação grave àquele encargo na atitude de médico que, findo seu horário de trabalho, abandona unidade de urgência em Centro de Saúde, com a plena consciência de que, durante algumas horas, não haveria a possibilidade de presença no local de qualquer outro médico.

De destacar-se a necessidade de busca de maiores resultados com a atividade dos entes da Administração Direta, preocupação sentida com a necessidade de

66 AMS 42.185 - RJ (TRF - 2 Reg., ac. un., rel. Des. Federal. Paulo Espírito Santo, julg. em 24-04-2002) e AI 2002.02.01.005505 - 1 (TRF - 2 Reg., ac. un., rel. Des. Federal. Tânia Heine, julg. 19-11-2002).

67 Interessante, no particular, a abordagem de Leonardo José Andriolo (Eficiência e desenvolvimento de recursos humanos nas administrações municipais: considerações à luz da Emenda Constitucional $n^{\circ} 19 / 98$ e das teorias organizacionais. Revista do Tribunal de Contas do Estado. Porto Alegre, n. 29, p. 148-151).

68 Rel. São Pedro, Acórdão de 25-11-2003. Disponível em www.sta.mj.pt. Acesso em: 29 out. 2004. 
ampliação de sua autonomia gerencial, orçamentária e financeira através de contrato de gestão e da estipulação de formas específicas e simplificadas de licitação ${ }^{69}$.

Área que desperta especial atenção é a dos serviços públicos. A transferência, com as recentes privatizações, da execução da maioria daqueles a concessionários privados, em substituição a empresas públicas e sociedades de economia mista, não reduziu o papel da função administrativa nesse setor, tendo-o, de modo inverso, elevado bastante.

Tanto a Lei $8.987 / 95\left(\right.$ art. $6^{\circ}, \S 1^{\circ}$ ) quanto o Código de Defesa do Consumidor (art. 22, caput) estatuem a imposição de serviços públicos eficientes, o que acarreta o dever do poder concedente de fiscalizar a sua pronta execução, a fim de aferir a qualidade das prestações de que é beneficiária a coletividade. Indispensável, para a consecução desse ideal, a pronta implementação do art. $37, \S 3^{\circ}$, I e II, da Lei Máxima ${ }^{70}$.

Uma amostra jurisprudencial do respeito da eficiência nessa seara pode ser vislumbrada na $\mathrm{AC}$ 2001.01.00.020121-0/DF ${ }^{71}$, onde foram anulados atos administrativos que deferiram a empresas de transporte coletivo autorização para a exploração de determinadas linhas, ressaltando-se que a exclusividade na execução de um serviço público é inteiramente contrária ao interesse público, conspirando em detrimento da maior agilidade e qualidade das prestações a serem fruídas pelos usuários.

No âmbito do procedimento administrativo que, na atualidade, constitui paradigma da atuação da Administração Pública contemporânea, a eficiência desperta peculiar importância.

69 Conferir, nessa direção, o deliberado pelo Supremo Tribunal Federal na ADIN 1.668 - DF (Pleno, mv, rel. Marco Aurélio, DJU de 16-04-2004), na qual foi reputado compatível com a Lei Magna os arts. 54 e 55, ambos da Lei 9.472/97, que instituíram novas modalidades de licitação sob as denominações de consulta e pregão, permitindo sua disciplina, a nível regulamentar, pela ANATEL. Ao indigitar os pontos de contato da inovação trazida ao art. 37, caput, pela EC 19/98, Renato Lopes Becho (Princípio da eficiência da Administração Pública. Boletim de Direito Administrativo. São Paulo, p. 440, jul. 1999.) refere-se à ampliação da autonomia administrativa de órgãos da Administração Direta e Indireta (art. $37, \S 8^{\circ}, \mathrm{CF}$ ) e a avaliação de desempenho e responsabilidade dos administradores das sociedades de economia mista e empresas públicas que explorem atividade econômica.

70 Uma breve observação: a menção pelo chefe do Poder Executivo Federal, no Plano Diretor da Reforma do Aparelho do Estado, a que "o princípio correspondente é o da eficiência, ou seja, a busca de uma relação ótima entre qualidade e custo dos serviços colocados à disposição do público" (item 5.2, Setores do Estado e Tipos de Gestão), a despeito de referir-se ao princípio em tela, procurando modelar o seu conteúdo, não possui relação com os serviços públicos objetos de concessão ou permissão. Conforme a oração anterior, dita exposição de motivos fez alusão às atividades exclusivas do Estado (competência regulamentar, fiscalização e fomento) e serviços não-exclusivos, como é o caso da saúde e da educação que não estão compreendidos pelo conceito stricto sensu de serviços públicos.

71 TRF - 1" Reg., 5" T., mv, rel. Juiz Antônio Cláudio Macedo da Silva (convocado), julg. em 21-04-2004. Malgrado omissa a ementa, o voto do relator se refere, às explícitas, que a intervenção administrativa impugnada restringe, de forma desproporcional, o princípio da eficiência na prestação dos serviços públicos. No mesmo sentido, conferir a AC 1999.01.00.089520 - 6 - DF (TRF - 1‘ Reg., 1* T., mv, rel. Juiz João Batista Moreira (convocado), julg. em 16-06-2000). 
A movimentação administrativa eficiente pressupõe, como sustenta Egon Bockmann Moreira ${ }^{72}$, o desenvolvimento de procedimento célere, simples, com finalidade pré-definida, econômico e efetivo ${ }^{73}$.

Ciosa da necessidade de rapidez na conclusão dos procedimentos administrativos, a Lei $9.784 / 99^{74}$ estatuiu as seguintes prescrições: a) obrigatoriedade de intimação das partes com a antecedência mínima de três dias para os atos de produção de prova (art. 41); b) fixação do prazo de quinze dias para a emissão de parecer de órgão consultivo, com a previsão de que, caso se trate de opinamento obrigatório, mas não vinculativo, o procedimento voltará ao seu curso e será decidido com sua dispensa (art. $42,2^{\circ}$ ); c) prazo máximo de dez dias para a apresentação de razões finais pelos interessados; d) dever de emissão de decisões finais no intervalo de trinta dias, prorrogável, com motivação, por igual período (art. 49); e) estipulação do prazo de dez dias para a interposição de recursos, bem assim de trinta dias para a sua decisão, contados estes do recebimento dos autos pelo órgão competente (art. 59, caput, e $1^{\circ}$ ).

O imperativo de celeridade reflete-se, como consta de lição de Luís S. Cabral de Moncada, citada no tópico 2, através do encargo de conclusão dos procedimentos sancionatórios em prazo aceitável, tanto que as Leis 8.112/90 (art. 142) e Lei $9.873 / 99$ (art. $1^{\circ}$ ), estabelecem intervalos nos quais se opera a prescrição administrativa.

A relevância do combate à mora administrativa, a qual costuma prestigiar uma Administração ineficiente, vem sendo alvo de salutar preocupação do Judiciário. Um meritório exemplo está no REsp 531.349 - RS, no qual se manteve sentença que determinou ao órgão administrativo competente que se abstivesse de tolher a atuação da demandante, na qualidade de rádio comunitária, enquanto não expedida a decisão de seu pleito de autorização de funcionamento, formulado há mais de três anos. $\mathrm{Na}$ sua fundamentação, o em. relator Min. José Delgado ${ }^{75}$ enfatizou que a atuação do poder concedente deve observar prazos razoáveis para a instrução e conclusão dos

72 Processo administrativo e princípio da eficiência. In: SUNDFELD, Carlos Ari e ANDRÉS MUÑOZ, Guillermo (Coord.). As leis de processo administrativo - Lei Federal 9.784/99 e Lei Paulista 10.177/98. São Paulo: Malheiros Editores, 2000. p. 333-340.

73 Sistematizando as dimensões do procedimento justo, Vera Scarpinela Bueno (As leis de procedimento administrativo: uma leitura operacional do princípio constitucional da eficiência. In: SUNDFELD, Carlos Ari e ANDRÉS MUÑOZ, Guillermo (Coord.). As leis de processo administrativo - Lei Federal 9.784/99 e Lei Paulista 10.177/98. São Paulo: Malheiros Editores, 2000, p. 362.) anota aquela da eficiência, apontando, nesse ponto, para o seu desenvolvimento com celeridade e racionalização. Uma abordagem entre eficiência e princípio administrativo é encontradiça em Davi Chicóski (O princípio da eficiência e o juìocedimento administrativo. Revista de Direito Administrativo. Rio de Janeiro, n. 237, p. 93-118, jul./set. 2004).

74 A Lei 10.177 do Estado de São Paulo, de 30 de dezembro de 1998, previu, no seu art. 32, de modo individuado, prazos para a prática dos diversos atos procedimentais, mencionando no art. 33 que o prazo máximo até a respectiva decisão será o de cento e vinte dias.

$75 \quad 1^{2}$. T., ac. un., DJU de 09-08-2004. 
procedimentos de autorização para funcionamento, pena de maltrato dos princípios da eficiência e da razoabilidade. Outras decisões nessa direção se seguiram ${ }^{76}$.

Por procedimento simples dever-se-á entender aquele que não se reveste de formalidades desnecessárias, não essenciais à tutela dos direitos das partes, e cujos atos sejam vazados em linguagem acessível ao cidadão de inteligência média.

Os incisos VIII e IX do art. $2^{\circ}$, parágrafo único, da Lei $9.784 / 99$, permitem essa compreensão quando aludem à "observância das formalidades essenciais à garantia dos direitos dos administrados" e à "adoção de formas simples, suficientes para propiciar adequado grau de certeza, segurança e respeito aos direitos dos administrados".

A finalidade pré-definida se impõe pela necessidade de que não devem ser instaurados procedimentos de forma aleatória, sem um objetivo claro, enquanto que a economia apregoa que se evitem repetições desnecessárias dos respectivos atos, encontrando concreção na instrumentalidade das formas e na regra da preclusão. Isto sem contar o estabelecimento de prazos para a realização de fases do procedimento e para que seja tomada a decisão final.

E, por último, a efetividade procedimental diz respeito a que o procedimento deve possuir a aptidão de meio ou instrumento para realizar os fins de interesse público a que a Administração está jungida.

De acrescentar-se, como reforço às características acima, que o princípio da eficiência reclama a possibilidade dos procedimentos administrativos, envolvendo interesses da Administração e dos particulares serem solucionados mediante instrumentos consensuais.

Essa tendência, atualmente, está bem presente no estrangeiro, bastando que se observem a figura do contrato de transação dos $\S \S 54$ e 55 da Lei de Procedimento

76 Interessante consultar o(a): a) MS 7.765 - DF (STJ, 1' S. ac. un., rel. Min. Paulo Medina, DJU de 14-10-2002), a retratar a concessão de segurança sob o amparo do princípio da eficiência, que exige, nas decisões administrativas, criteriosa análise dos elementos de convicção conjugada com a observância de prazo razoável, assinando-se o interregno de sessenta dias ao Ministro de Estados das Comunicações, para que se pronuncie sobre o pedido de autorização para funcionamento da impetrante como rádio comunitária, protocolado há mais de três anos antes da impetração; b) MS 9.420 -DF (STJ, 3* S., ac. un., rel. Min. Laurita Vaz, DJU de 06-09-2004), no qual, a partir do entendimento de que o princípio da eficiência não tolera a postergação indefinida da conclusão de procedimento administrativo, assinou-se o prazo de sessenta dias para que o Ministro de Estado da Justiça profira decisão final no processo administrativo do impetrante, uma vez aproximadamente dois anos da impetração viera a lume parecer da Comissão de Anistia; c) AMS 1997.01.00.0177243-DF (TRF - 1* Reg., 1* T., ac. un., rel. Juiz Ricardo Machado Rabelo, julg. em 09-11-2000), onde, não obstante denegada a segurança por deficiência probatória, o voto do relator asseverou que à vista do princípio da eficiência não pode o administrador omitir-se em se manifestar, positiva ou negativamente, em prazo razoável, sobre pedidos dos administrados; d) REOMS 77.308 - PB (TRF - 5' Reg., 3 T., ac. un., rel. Juiz Paulo Cordeiro (convocado), DJU - II de 15-10-2003), consoante o qual, apos forte realce do princípio da eficiência administrativa, entendeu-se configurar abuso de poder na omissão atribuída ao Magnífico Reitor da UFPB que, até meados do ano de 2000, ainda não expedira diploma de conclusão do Curso de Especialização em Novas Tecnologias da Educação, concluído pela impetrante desde novembro de 1998. 
Administrativo da República Federativa da Alemanha (Verwaltungsverfahrensgesetz), de 25 de maio de 1976, dos acordos previstos no art. 11 da Legge 241/1990 e o término convencional do art. 88 da espanhola Ley 30/1992.

Entre nós, sensível avanço pode ser registrado no RE $253.885-\mathrm{MG}^{77}$, assentada onde o Supremo Tribunal Federal, mesmo sem negar a relevância do princípio da indisponibilidade do interesse público, sustentou que este deverá ser atenuado quando a Administração, mesmo sem lei autorizadora, enverede pela solução que melhor resguarde aquele interesse. Tratava-se de transação firmada entre o Município de Santa Rita do Sapucaí e duas servidoras municipais, com vistas a pôr cobro a processo judicial com mais de três anos de tramitação, a qual, a despeito da ausência de autorização legislativa, foi reputada válida por não ser onerosa e nem gerar gravame patrimonial, recaindo no pagamento de salário, prestação alimentar, e que fora indevidamente retido.

Mesmo se considerando que a Lei $9.784 / 99$ não prevê competência para a celebração de acordos ${ }^{78}$, com vistas à extinção dos procedimentos administrativos no âmbito federal, tal é plenamente admissível nos limites expostos pelo Pretório Excelso e, em nenhum momento, poder-se-á cogitar de ofensa ao princípio da legalidade.

Isso porque a atual convivência entre a Administração e o sistema jurídico não se faz unicamente na forma de uma vinculação positiva diante da lei que, durante largo espaço de tempo, predominou entre nós com base em ensinamento de Hely Lopes Meirelles ${ }^{79}$.

Pelo contrário, a submissão da Administração à lei ora se dá como fundamento prévio e necessário de determinada ação (vinculação positiva), ora como um mero limite externo à livre ação do sujeito (vinculação negativa). Nesta última hipótese, onde se têm situações não abrangidas pela reserva legal, o administrador pode realizar condutas sem necessidade de prévia habilitação em preceito de hierarquia legislativa, com a única condição de que não contradigam proibições estabelecidas na Constituição e em sede legal ${ }^{80}$.

77 Ac. un., rel. Min. Ellen Gracie, DJU de 21 -06-2002, p. 001 18. Evocou-se precedente no Agravo de Instrumento 52.181 - GB (STF, Pleno, ac. un., rel. Min. Bilac Pinto, RTJ 68/382), em cuja motivação salientou não haver incompatibilidade entre a fazenda pública e o juízo arbitral. A leitura de fração da ementa é assaz explicativa: " 1 - Legalidade do Juízo Arbitral, que o nosso Direito sempre admitiu e consagrou, até mesmo nas causas contra a Fazenda. Precedente do Supremo Tribunal Federal."

78 De destacar que o art. 23, XV, da Lei 8.987/95, prevê, nas concessões, a possibilidade de concedente e concessionário resolverem amigavelmente suas controvérsias contratuais.

79 Sustentava o saudoso doutrinador: "Na Administração Pública, não há liberdade nem vontade pessoal. Enquanto na administração particular é lícito fazer tudo que a lei não proíbe, na Administração Pública só é permitido fazer o que a lei autoriza. A lei para o particular, significa "pode fazer assim"; para o administrador público significa "deve fazer assim" (Direito administrativo brasileiro. 14. ed. São Paulo: Revista dos Tribunais, 1989. p. 78).

80 Princípios de derecho administrativo. 4. ed. Madri: Editorial Centro de Estudos Ramón Areces, S.A., 2002. v. I, p. 92-95. 
Antes de encerrar este tópico, desperta atenção a abordagem, ainda que em breves linhas, da eficiência como fator determinante da responsabilidade estatal.

Embora não se duvide que, no particular dos atos comissivos, a responsabilidade estatal se guie pela teoria do risco administrativo, consagrado no art. $37, \S 6^{\circ}$, da Lei Básica, de modo que a forma de atuação do agente público não ostente relevância para o surgimento do dever de indenizar, o qual emerge do nexo de causalidade entre o evento e o dano, não se poderá deixar de ponderar a influência que o comportamento do aparato administrativo possua no particular de danos oriundos de omissão.

$\hat{E}$ que, cuidando-se de atos omissivos, tem-se invocado, para fundamentar a responsabilidade do Estado, a teoria da culpa administrativa (faute de service) ${ }^{81}$.

Discorrendo sobre o assunto, Vedel \& Delvolvé precisam que a

culpa de serviço é a culpa imputável a um ou vários agentes do serviço, e que não tem a característica de culpa pessoal destacável do serviço" ${ }^{82}$, podendo "consistir numa ação como numa abstenção, num comportamento voluntário como numa imprudência ou numa falta de aptidão. Ela pode ser constituída por um ato administrativo como por uma simples operação material. Ela pode consistir num defeito de organização do serviço como numa fraqueza de seu funcionamento ${ }^{83}$.

Por sua vez, Jean Rivero ${ }^{84}$ aponta, inicialmente, a deficiência no funcionamento anormal do serviço. Isto porque de toda atuação estatal se deve esperar um nível médio de qualidade, variável de acordo com a natureza da missão confiada e as circunstâncias do caso concreto. A culpa surgirá quando a prestação do serviço situar-se abaixo de tal padrão.

$\mathrm{Na}$ doutrina nacional, bem qualificou a teoria da culpa administrativa José Cretella Júnior, dizendo: "O serviço público deve funcionar bem: é a regra. Às vezes, entretanto, o serviço público funciona mal. O serviço, além de poder funcionar mal, pode não funcionar ou pode funcionar atrasado e, nestes casos, o Estado é obrigado sempre a indenizar" 85 .

Para a aferição, no caso concreto, da má prestação do serviço público, a jurisprudência francesa - narra Jacques Moreau ${ }^{86}$ - delineia a necessidade do exame de

81 Cf. Oswaldo Aranha Bandeira de Mello (Principios gerais de direito administrativo. 2. ed. Rio de Janeiro: Forense, 1979. v. II, p. 487).

82 "faute de service est la faute imputable à un ou plusieurs agents du service et qui n'a pas le caractère de faute personelle détachable du service". (Droit administratif. 12. ed. Paris: PUF, 1992. Tomo 1, p. 581 ).

83 "consister dans une action comme une dans une abstention, dans un agissement volontaire comme dans une imprudence ou une maladresse. Elle peut être constituée par un acte administratif comme par une simple opération matérielle. Elle peut consister dans un défaut d'organisation du service commme dans une défaillance de son fonctionnement". (ibid. p. 581).

84 Direito Administrativo. Tradução: Rogério Ehrhardt Soares. Coimbra: Almedina, 1981. p. 320.

85 Manual de Direito Administrativo. 2. ed. Rio de Janeiro: Forense, 1979. p. 343-344.

86 Droit administratif. Paris: Presses Universitaires de France, 1989. p. 380-381. 
algumas particularidades, relacionadas às circunstâncias de tempo e de lugar, aos meios concretos de que dispõe aquele, à previsibilidade tanto do fato quanto da ação administrativa e ao comportamento do lesado.

Malgrado a faute de service possa se referir também a atos positivos, o certo é que esta se encontra fortemente conexa à necessidade de bom funcionamento da atividade administrativa, objetivo perseguido pelo dever de eficiência. A responsabilidade, como visto, advém pela prestação de um serviço ou atendimento ineficiente diante de determinada situação.

Isso porque da atividade administrativa os particulares devem esperar um nível médio de qualidade e, quando esta não ocorre, há um funcionamento anormal do serviço que empenha a responsabilidade estatal. Sem sombra de dúvida, o dever de reparar tem seu fundamento na ausência de eficiência da atuação estatal.

No cotidiano da composição de litígios, os pretórios ofertam límpida demonstração de quão imbricadas estão eficiência e responsabilidade estatal.

Dois arestos bem exemplificam a assertiva. O primeiro deles recai no $R E$ 258.726-5 - $\mathrm{AL}^{87}$, sede em que o Supremo Tribunal Federal manteve decisão que reconheceu a obrigação de indenizar em desfavor da União por omissão na fiscalização dos serviços de navegação aérea, tendo em vista que, mesmo não existindo o dever do Departamento de Aviação Civil em inspecionar todas as aeronaves no momento antecedente à decolagem, até por tal ser materialmente impossível, o aparelho que patrocinara o sinistro se encontrava em estado de tal modo aterrador, o qual era suficiente para atestar, às escâncaras, a omissão dos deveres mínimos de fiscalização. A espécie retrata, com clarividência, a ineficiência em que incorreu a atividade administrativa de polícia.

O outro julgado na $\mathrm{AC} 198.873-\mathrm{RN}^{88}$, em cujo deslinde a $3^{\mathrm{a}}$ Turma do Tribunal Regional Federal da $5^{\text {a }}$ Região negou provimento a apelações interpostas por vários municípios, mantendo sentença que julgara procedente ação civil pública promovida pelo Ministério Público Federal, ao argumento de que a teoria da culpa administrativa, dizendo respeito à prestação insatisfatória de serviço estatal, estaria caracterizada pela ausência de ação administrativa eficiente de combate à dengue que, não obstante a notória notícia de seu retorno ao território nacional há mais de onze anos, propiciou sua proliferação pela não execução de política sanitária segundo os padrões esperados do aparelho administrativo.

\section{Limites e controle judicial da eficiência.}

O princípio da eficiência, a despeito de seu porte constitucional, não ostenta valor absoluto. De logo, é de notar-se o seu concerto perante os demais princípios da Administração.

87 1* T., ac. un., rel. Min. Sepúlveda Pertence, DJU de 14-06-2002.

$88 \mathrm{Mv}$, rel. Juiz Edílson Nobre (convocado), julg. em 13.11.2003, publicado no DJU de 18.12.2003. 
Tal postulado ostenta caráter instrumental e, por isso, não está desvinculado dos demais princípios retores da Administração Pública e nem, muito menos, é um superprincípio.

Com relação à legalidade, não obstante à primeira vista se possa visualizar estado de oposição, é preciso enfatizar que, contrariamente, há sensível harmonia. Isso porque a eficiência, ao invés de rejeitar a adstrição do administrador à juridicidade, incorpora a esta um novo sentido, de cunho substancial, de maneira que, além da mera observância à formalidade, se busque o interesse público pelo alcance de determinados resultados quando da realização de atos administrativos ${ }^{89}$.

É certo que, em compasso com lição de Maria Sylvia Zanella di Pietro ${ }^{90}$, a recepção pela Administração da eficiência não poderá ocorrer com perfeita identidade à realidade das empresas, tanto que inadmissível a sua incidência em franca contrariedade ao ordenamento jurídico.

À guisa de exemplo, verifica-se que, enquanto o empresário, com vistas à redução de custos, ou a incrementar maior produtividade. obstada por empregado com rendimento não desejado, pode optar, sem maiores obstáculos, pela via da dispensa, o administrador público não se encontra a tanto autorizado. Isso não significa, porém, que, no setor público, não se possa tomar providências no sentido de maiores resultados, mas, para tanto, ter-se-ia de lançar mão dos mecanismos constitucionais relativos ao quebrantamento da estabilidade, ou com o provimento dos cargos em comissão por critérios técnicos e não exclusivamente político-partidários.

Igualmente, não se pode dissociar a eficiência da moralidade pública, haja vista que, como já visto neste trabalho, aquela pressupõe o respeito às regras da boa administração. Um programa ousado de obras públicas, seja pela moderna tecnologia na sua implementação, seja pelos benefícios a serem acarretados em prol da coletividade, não poderá ser concretizado a contento se suprimida, sem motivo justificado, a realização de licitação, outorgando-se o objeto do contrato a empresa que possua afinidades com os agentes incumbidos do governo da entidade política. $O$ reclamo em torno do atuar eficiente não respalda tal proceder.

Também de observar-se que a impessoalidade não colide, antes se conforma com a eficiência. É que, através daquela, patrocina-se a atuação da Administração em busca do interesse público, o que, estreme de dúvidas, não é diverso do objetivado pela eficiência, com a otimização de resultados pela ação daquela.

89 Digno de remissão o escólio de Adilson de Abreu Dallari (Privatização, eficiência e responsabilidade. In: MOREIRA NETO, Diogo de Figueiredo (Coord.). Uma avaliação das tendências contemporâneas do direito administrativo - obra em homenagem a Eduardo García de Enterría. Rio de Janeiro: Renovar, 2003. p. 228.) que, embora mencione não derrogar o princípio da eficiência o da legalidade, a inserção daquele no sistema jurídico requer que a Administração avance além do mero cumprimento à letra legal, devendo buscar a forma mais eficiente de cumprir esta, adotando a solução que, diante das peculiaridades do caso concretc, melhor permita alcançar o interesse público.

90 Parcerius na Administração Pública. 4. ed. São Paulo: Atlas, 2002. p. 241-242. 
A publicidade, com vistas a satisfazer exigência de transparência das manifestações administrativas, ou como garantia do administrado, não confronta com a eficiência. Uma Administração transparente propicia seu controle de maneira mais satisfatória, singularidade que, ao invés de contrapor-se, amolda-se à eficiência, que pressupõe o exame dos resultados produzidos por aquela diante da consecução do interesse público. Basta notar que o art. 74, II, da Constituição, mantém íntima correlação com a eficiência, ao mencionar que a manutenção de controle interno no âmbito dos poderes Legislativo, Executivo e Judiciário, destina-se a comprovar a avaliação dos resultados, quanto à eficácia e eficiência, da gestão orçamentária, patrimonial e financeira dos órgãos e entidades integrantes da Administração Federal.

De outro lado, o respeito aos direitos do administrado no procedimento administrativo propende àquilo que se pode denominar de procedimento justo, ideal para cuja obtenção não é dispensável a noção de eficiência.

Não perder de vista que o princípio da eficiência não deverá ser aplicado em detrimento dos direitos fundamentais. A noção de juridicidade, como representativa do novo perfil do princípio da legalidade, assim impõe.

Indispensável, na coexistência entre eficiência e os demais princípios administrativos e direitos fundamentais, o manejo do princípio da proporcionalidade, para que, numa ponderação de valores, possa-se optar, no caso concreto, pelo valor constitucional mais satisfatório ao interesse público ${ }^{91}$.

Aspecto interessante condiz com a utilização do principio da eficiência como parâmetro para o controle judicial da Administração. As referências constantes do tópico retro já demonstram, só por só, a afirmativa. Todavia, avulta a relevância do debate quando se investiga se, nos atos decorrentes da competência discricionária, poderia o Judiciário invalidá-los sob o argumento da sua ineficiência. Mais precisamente, importante saber se nas hipóteses onde o administrador, para atingir determinado fim público, possui o direito de escolha entre duas opções juridicamente possíveis, o postulado em comento exigiria fosse tomada a solução que melhor atendesse tal objetivo.

A doutrina se controverte. Vladimir da Rocha França se pronuncia sobre a negativa, aduzindo:

"Analisar a eficiência da ação administrativa é analisar a esfera de sua discricionariedade. A opção por um critério técnico específico, se conciliado com os cânones do regime administrativo, fica isenta de invalidação judicial por ineficiência. Não cabe ao Poder Judiciário definir a melhor técnica aplicável, mas sim se esta ateve-se aos limites do ordenamento jurídico" 92 .

91 Confira-se afirmativa de Alexandre Santos Aragão (O princípio da eficiência. Revista de Direito Administrativo. Rio de Janeiro, n. 237, p., 4, jul./set. 2004.

92 Eficiência administrativa na Constituição Federal. Revista dos Tribunais. São Paulo, ano 89, v. 777 , p. 751 , jul. 2000 . 
Diversamente, tem-se o posicionamento de Marcelo Harger ${ }^{93}$, para quem apresenta relevância a prática dos atos discricionários, de modo que o administrador não poderá optar, de maneira aleatória, entre as várias opções disponíveis. Não haveria, portanto, margem de escolha, principalmente quando o caso concreto venha a demonstrar, dentre as várias alternativas, a que se revista como melhor. Caso não realizada tal escolha, a invalidade do ato administrativo seria a consequência. A eficiência, assim, serve de baliza para a atuação discricionária.

No mesmo diapasão, Emerson Gabardo, ao inferir ser " muito mais consentâneo ao interesse público que seja admitido ao Poder Judiciário a possibilidade de anulação do ato administrativo inclusive em função de sua ineficiência" ${ }^{94}$, sem que possa cogitar de afronta ao princípio da separação de poderes, frisando, mais adiante, ser admissível a fiscalização em favor da atuação ótima.

Com a devida reverência aos favoráveis à ampliação do controle jurisdicional, penso que a atuação do juiz não poderá implicar substituição do administrador.

O problema, que nos remete à discricionariedade técnica, é solucionado, com precisão, por Cassagne ${ }^{95}$, para quem, a bem da verdade, o juízo técnico não traduz escolha para o administrador, não havendo que se falar em discricionariedade. A liberdade de eleição daquele é quanto ao método, técnica ou procedimento científico, para se realizar determinado objetivo e, nesse ponto, descabe a intromissão do magistrado.

Suponha-se que determinado edifício ameace ruína e, para evitar dano à coletividade, apresente-se imprescindível a sua destruição. O juízo técnico quanto a isto é incontestável e não poderá ser desconsiderado pelo administrador. Contudo, o meio pelo qual este procederá para atingir o objetivo ( $v . g$. , demolição ou implosão) poderá, desde que não prejudique terceiros, ser de livre escolha, não havendo que se cogitar de intervenção do Judiciário. Muitas vezes a Administração manifesta suas opções por vinculação à execução orçamentária, da qual não pode se afastar. O mesmo se aplica quanto à forma de realização de determinada construção, considerada conveniente ao interesse público.

Além do mais, não se afigura de todo lícito ao Judiciário suprimir a liberdade de conformação da Administração em proceder a determinadas atuações, como a realização de obras públicas, tendo em vista, regra geral, dever preponderar o programa de ação estabelecido pelo governante, eleito para gerir os interesses da comunidade.

Apropriadas, para o encerramento deste breve enfoque, as lúcidas palavras de Adilson de Abreu Dallari:

93 Reflexōes iniciais sobre o princípio da eficiência. Boletim de Direito Administrativo. São Paulo, p. 808, dez. 1999.

94 Princípio constitucional da eficiência administrativa. São Paulo: Dialética, 2002. p. 141-142.

95 Fragmentos de derecho administrativo - entre la justicia, la economia y la política. Buenos Aires: Jose Luís Depalma Editor, 2003. p. 101. 
Não há como aceitar a competência do Judiciário para decidir sobre prioridades da Administração, pois isso viola o princípio da separação de poderes (ou, mais precisamente, de funções governamentais), agride o princípio representativo, não se coaduna com o planejamento democrático e desmantela todo o sistema de elaboração e execução orçamentária ${ }^{96}$.

Somente para fins ilustrativos, gostaria de salientar que o Conselho de Estado da França, no que toca às expropriações, tem alargado o domínio da legalidade do ato de declaração de utilidade pública, examinando se este atende ao bilan-coûtavantages, de modo a restar assentado, no aresto Ville Nouvelle - Lille Est, de 28 de maio de 1971, que "uma operação só pode ser legalmente declarada de utilidade pública se os atentados à propriedade privada, o custo financeiro e eventualmente os inconvenientes de ordem social que ela comporta não forem excessivos em relação ao interesse que ela apresenta" (Fernando Alves Correia. As garantias do particular na expropriação por utilidade pública. Coimbra: 1982. p. 183). Seguiram-se os arestos Sociedade Civil Santa-Maria da Assunção, de 20 de outubro de 1972, e Sieur Grassin, de 23 de outubro de 1973. No segundo julgado, foi invalidada declaração de utilidade pública, visando à construção de um aeródromo de categoria $D$ na comuna La Peyratte. Entendeu-se a não correspondência da obra às necessidades reais dos meios econômicos da região. Como se vê, o princípio da proporcionalidade é que foi, na realidade, a medida da intervenção jurisdicional.

\section{Conclusões}

Ao cabo de tudo quanto restou exposto, eis, sumariadas, as conclusões abaixo:

a) superado o positivismo estrito ou legalista, as Constituições promulgadas a partir da metade do século XX aderiram ao que, na cultura jurídica, convencionou-se chamar de pós-modernismo ou pós-positivismo, de maneira a ajustar a idéia de legalidade à conformidade com o Direito, movimento a grassar no direito administrativo, o qual passa a fundar-se em preceitos oriundos dos tradicionais princípios gerais do direito e, mais recentemente, daqueles resultantes dos imperativos da vida coletiva, como é o caso da eficiência na ação administrativa;

b) os modernos ordenamentos estrangeiros, seja no plano constitucional (art. 97, Constituição italiana; art. 103, Constituição hispânica; e art. $267^{\circ}$, Constituição da República Portuguesa) como no das respectivas leis de procedimento administrativo (Legge 241/1990, Ley 19.549/1972, Decreto-lei 442/1991 e Ley 30/1992), passaram a consagrar, sob diversos rótulos (imparcialidade, bom andamento, eficiência ou eficácia), novo parâmetro no que concerne à máxima da legalidade administrativa, acrescendo-lhe um preponderante lastro substancial em detrimento do seu aspecto

96 Privatização, eficiência e responsabilidade. In: MOREIRA NETO, Diogo de Figueiredo (Coord.). Uma avaliação das tendências contemporâneas do direito administrativo - obra em homenagem a Eduardo García de Enterría. Rio de Janeiro: Renovar, 2003. p. 228. 
formal, para que a Administração persiga o interesse público de forma célere, simplificada e efetiva;

c) a eficiência administrativa, demais de lídimo princípio jurídico, cuja consagração aqui precedeu, em muito, à EC 19/98, representa imperativo a que a Administração Pública melhor atenda à consecução de seus objetivos, com o menor custo possível, satisfazendo as exigências de atuação média do aparato administrativo, sem descurar do respeito às regras de boa administração, juntamente com o propósito de simplificar suas posturas e de proceder à resolução de conflitos por mecanismos consensuais; daí segue-se, na sua implementação, consequiências em institutos basilares do direito administrativo, tais como os atos administrativos, a licitação e os contratos administrativos, o poder de polícia, os servidores públicos, os serviços públicos, o procedimento administrativo e a responsabilidade estatal;

d) o princípio da eficiência, apesar de inaugurar um novo modelo de administrar a coisa pública, denominado gerencial, não ostenta primazia ante os demais cânones regentes da Administração Pública, antes com estes mantendo relacionamento harmônico, bem assim não se descurando da inevitável reverência aos direitos fundamentais;

e) conquanto irrefutável a inserção da eficiência no bloco de juridicidade, para fins de controle jurisdicional da Administração, importa ponderar que tal competência não se espraia ao ponto de eliminar a opção discricionária entre duas soluções justas, prevalecendo o entendimento válido quanto à discricionariedade técnica, de maneira que, enquanto o juízo oriundo do conhecimento específico se apresente impositivo ao administrador, a este pertence a liberdade de escolha quanto ao meio para atingi-lo, desde que não afete direito de terceiro, não sendo cabível a intervenção substitutiva do julgador. 